\title{
Testicular Sclerosing Sertoli Cell Tumor
}

National Cancer Institute

\section{Source}

National Cancer Institute. Testicular Sclerosing Sertoli Cell Tumor. NCI Thesaurus. Code C39945.

A rare testicular Sertoli cell tumor characterized by the presence of neoplastic tubules that are surrounded by a dense fibrotic stroma. 